\title{
Consequences of a mass mortality in populations of Eunicella singularis (Cnidaria: Octocorallia) in Menorca (NW Mediterranean)
}

\author{
Rafel Coma ${ }^{1, *}$, Cristina Linares ${ }^{1},{\text { Marta } \text { Ribes }^{2}, \text { David Diaz }^{3} \text {, Joaquim Garrabou }}^{4}$, \\ Enric Ballesteros ${ }^{1}$
}

${ }^{1}$ Centre d'Estudis Avançats de Blanes, Accés Cala Sant Francesc 14, 17300 Blanes, Girona, Spain

${ }^{2}$ Institut de Ciències del Mar, Passeig Marítim 37-49, 08003 Barcelona, Spain

${ }^{3}$ Instituto Español de Oceanografía, Centro Oceanográfico de Baleares, C/ Moll de Ponent s/n, 07015 Palma de Mallorca, Spain

${ }^{4}$ UMR 6540-DIMAR CNRS/Université de la Méditerranée, Station Marine d'Endoume, rue de la Batterie des Lions, 13007 Marseille, France

\begin{abstract}
At the end of the boreal summer of 1999, many invertebrates in hard-bottom communities in the NW Mediterranean Sea suffered an episode of mass mortality. Our study examined the effects of this event on populations of the temperate octocoral Eunicella singularis at Menorca (Balearic Islands). The event affected colonies over the entire depth range where the species is present $(15$ to $40 \mathrm{~m}$ ). Four years after the occurrence of the event, $59 \%$ of the colonies still exhibited some damage. The extent of injury of the colonies varied among locations, ranging between 37 and $67 \%$ with a mean of $50 \%$ of the colony surface. The proportion of dead colonies also varied among locations from 26 to $62 \%$, with an overall mean of $46 \%$ of the population. The proportion of dead colonies was inversely correlated with density. Current size distribution of the colonies indicated the occurrence of low recruitment during the years subsequent to the mass mortality event. Our study demonstrates that the 1999 mass mortality event was geographically more extensive than previously thought (Menorca is located about 400 to $700 \mathrm{~km}$ from areas where mass mortality was previously reported, along the coast of Provence and Ligury). The mortality rate of E. singularis estimated for the Menorca populations was the highest value recorded to date for this species, showing that the delayed effects of the mortality event exerted a much greater impact on these populations than the immediate effects. Additional impacts result from a reduction in recruitment. These delayed consequences may lead to important changes in community composition, structure, processes and function, as gorgonians are key structural and functional organisms within these communities.
\end{abstract}

KEY WORDS: Coralligenous community · Gorgonian mortality · Injury · NW Mediterranean · Eunicella singularis $\cdot$ Partial mortality $\cdot$ Balearic Islands

Resale or republication not permitted without written consent of the publisher

\section{INTRODUCTION}

The complexity of habitat structure has been related to diversity in terrestrial and marine ecosystems (e.g. MacArthur et al. 1966). An increase in habitat structural complexity provides an increase in habitat and microhabitat types that positively affects species coexistence and diversity (Huston 1979). Much of the habitat structural complexity in marine benthic ecosystems may be explained by the physical complexity of the substratum and by the biogenic structure provided by engineering species (Jones et al. 1994). Ecosystem engineers such as corals, oysters, vermetid gastropods, sabelid worms and crustose coralline algae (see Bruno \& Bertness 2001 for a recent review), provide shade and shelter to other species by means of their biogenic structure. Therefore, significant changes in their abundance can strongly affect the organization and functioning of the community. 
Diseases and mass mortalities are affecting an increasing number of marine species worldwide, including many ecosystem engineers (Harvell et al. 1999, 2004). The increase of these strong disturbances has been linked with the serious decline in the conservation status of many species in marine ecosystems in response to global climate change (Hughes et al. 2003). This is especially evident in coral reefs, where the 1997-98 coral bleaching event appears to have been the most severe ever recorded (Wilkinson et al. 1999). Mediterranean benthic temperate ecosystems have also been affected by mass mortality events (see Coma \& Ribes 2003 for a review). In summer 1999, one of the largest mass mortality events occurred, and for the first time species from a wide variety of phyla covering hundreds of kilometers in the NW Mediterranean were affected (French and Italian coasts; Cerrano et al. 2000, Perez et al. 2000, Garrabou et al. 2001, Linares et al. 2005). Understanding the consequences of these major events is of key importance for the conservation of these affected communities, which are among the richest in the Mediterranean (Ballesteros 2006).

Gorgonians are common components of sublittoral Mediterranean benthic communities (Weinberg 1978). They play an important ecological role because they provide habitat for epifauna and increase the biomass and diversity of the community (Wendt et al. 1985). Therefore, survival of the sublittoral community may be closely linked to that of the habitat-forming species. Although gorgonians are host for numerous commensals, symbionts and parasites (e.g. Conradi et al. 2004), studies of population dynamics indicate that adult mortality is low and mainly due to detachment and overgrowth (Yoshioka \& Yoshioka 1991, Coma et al. 2004). Nevertheless, it has been recognized that the study of episodic events may contribute to the understanding of life history patterns of many long lived species - at least as much as, if not more than, the study of demographic parameters that occur during normal conditions (e.g. Boero 1996).

Data regarding the impact of the 1999 mass mortality event along the Provence coast and Ligurian sea were provided by Cerrano et al. (2000) and Perez et al. (2000). However, we still lack considerable knowledge of (1) the complete geographic and bathymetric extent of the event, (2) whether evaluation of the event, conducted shortly after its occurrence, was able to account for the total impact on the populations (see short versus long term assessment in Linares et al. 2005), and (3) the overall consequences of the event. These issues are crucial to the understanding of the role that these events may play in structuring hard-bottom communities, and to the design of management plans for the conservation of these diverse and complex communities.
The first aim of this study was to document that the mass mortality of invertebrates recorded in 1999 along the coasts of Provence (Perez et al. 2000) and Liguria (Cerrano et al. 2000) also affected the gorgonian population at Menorca (Balearic Islands). A second aim was to assess the long term consequences of the mortality event on populations of the gorgonian Eunicella singularis (Esper, 1791). The disturbance exerted on Mediterranean benthic populations by the 1999 event provided a highly valuable opportunity to evaluate the role of episodic disturbances on population dynamics of long-lived marine colonial organisms.

\section{MATERIALS AND METHODS}

A large mortality event affecting the populations of Eunicella singularis along the north coast of Menorca was observed in late summer 1999 during surveys conducted in the recently declared marine protected area (MPA) of the 'Reserva Marina del Nort de Menorca'. Given the magnitude of the event (Cerrano et al. 2000, Perez et al. 2000) and the capacity of our research team, a qualitative survey examining gorgonian populations over the Mediterranean coast of Spain was prioritized. This qualitative assessment indicated that Menorca was the only area along the coast of Spain where populations of this species were affected by the 1999 event. As no data on the long term consequences of the event on E. singularis were available, a quantitative assessment was conducted in June and July 2003 to examine the role of episodic disturbances on population dynamics of this species. Qualitative information on the change in populations between 1999 and 2003 was provided by a survey conducted by E. Ballesteros (as part of the description and mapping of the benthic communities of the MPA), and by the diving clubs operating within the study area. Diving clubs were very interested in the magnitude and effects of the mass mortality event. We described to them the observations reported from other Mediterranean areas, and diving club instructors were asked to report any relevant variation in the proportion of denuded axes on colonies of E. singulares (the clearest indicator that a mass mortality event has affected the populations in question).

Study sites for the quantitative surveys were located along the north coast of Menorca (Balearic Islands, NE Spain, NW Mediterranean), some of them within the MPA 'Reserva Marina del Nort de Menorca' (Fig. 1). Six sites, spaced at regular intervals along the north coast of Menorca, were sampled in order to cover the extent of the distribution of this species (Fig. 1). Sampling was performed via SCUBA diving. For each site, the following data on Eunicella singularis populations 


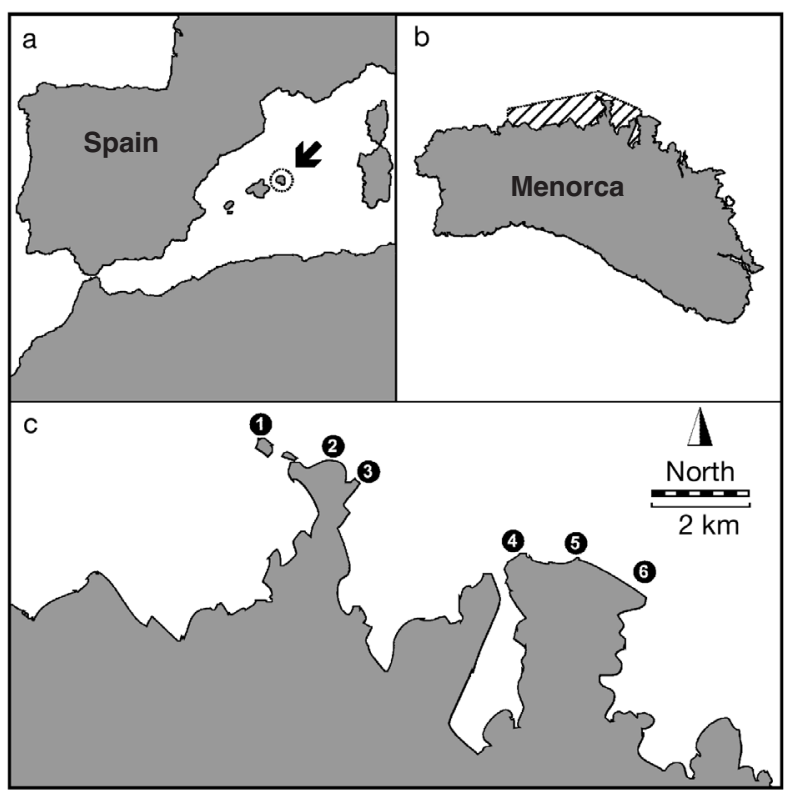

Fig. 1. Study sites. (a) Location of Menorca (Balearic Islands) in the NW Mediterranean. (b) Location of the Reserva Marina del Nort de Menorca on the north coast of Menorca. (c) Location of 6 study sites: (1) Illa des Porros, (2) Cap de Cavalleria, (3) Cap Roig-Patró Pere, (4) Escull de Na Ponça,

(5) Punta de Na Guiemassa and (6) Cova de Ses Bruixes

were obtained: depth distribution limits (min. and max.), density and size structure (at least at 1 depth range), and impact of mortality at several depths.

The standard error (SE)-sample size function was used to determine the minimum sample size needed to examine the density and extent of injury to colonies at each site. Preliminary sampling was conducted at 1 site (Cap Roig) by examining $17 \mathrm{~m}^{2}$ using $50 \times 50 \mathrm{~cm}$ quadrats randomly placed on the substrate between 15 and $20 \mathrm{~m}$ depth. The extent of injury to each colony was estimated as the proportion of the colony's total surface that had no tissue (i.e. denuded axis) and/or overgrowth by other organisms (as in Nalgelkerken et al. 1997). SE as a proportion of mean density decreased quickly with increasing sample size (Fig. 2a). The curve flattened out at a sample size of $1.75 \mathrm{~m}^{2}$, where the variance became about $5 \%$ of the mean. SE as a proportion of mean extent of injury also decreased quickly with increasing sample size (Fig. 2b). This curve flattened out at a sample size of 50 colonies, with variance of $\sim 10 \%$ of the mean. These results allowed us to determine the sample size needed to represent the density and degree of injury to the Eunicella singularis population at each of the sampling sites. On the basis of these results, we used at least 3 replicates of $2 \mathrm{~m}^{2}$ per location to estimate density and a minimum of 3 replicates of 100 colonies at each location to estimate the extent of injury of the colonies.
A transect randomly placed between 0 and $40 \mathrm{~m}$ was conducted at Cap Roig-Patró Pere to examine the variation in colony density with depth. At each depth interval $(5 \mathrm{~m}$ increments), $50 \times 50 \mathrm{~cm}$ randomly placed quadrats were used to quantify all colonies present. At 2 sites (Cap Roig-Patró Pere and Illa des Porros), random transects were conducted over the entire depth range of distribution to examine whether mass mortality exhibited any depth pattern. At each $5 \mathrm{~m}$ depth interval, the extent of injury of more than 100 colonies was also determined.

At all 6 sites, randomly placed quadrats within the depth range of maximum abundance (15 to $20 \mathrm{~m}$ ) were examined. At each site, a minimum of 3 replicates of the chosen minimum sample size $\left(2 \mathrm{~m}^{2}\right)$ were surveyed. Colony height, extent of colony injury and nature of epibionts were noted for each colony present within each quadrat. Colony height was measured with a ruler as the distance between the colony base and the longest tip. The extent of injury was estimated as described above. Epibionts were identified in situ at the level of large taxonomic groups, but most common

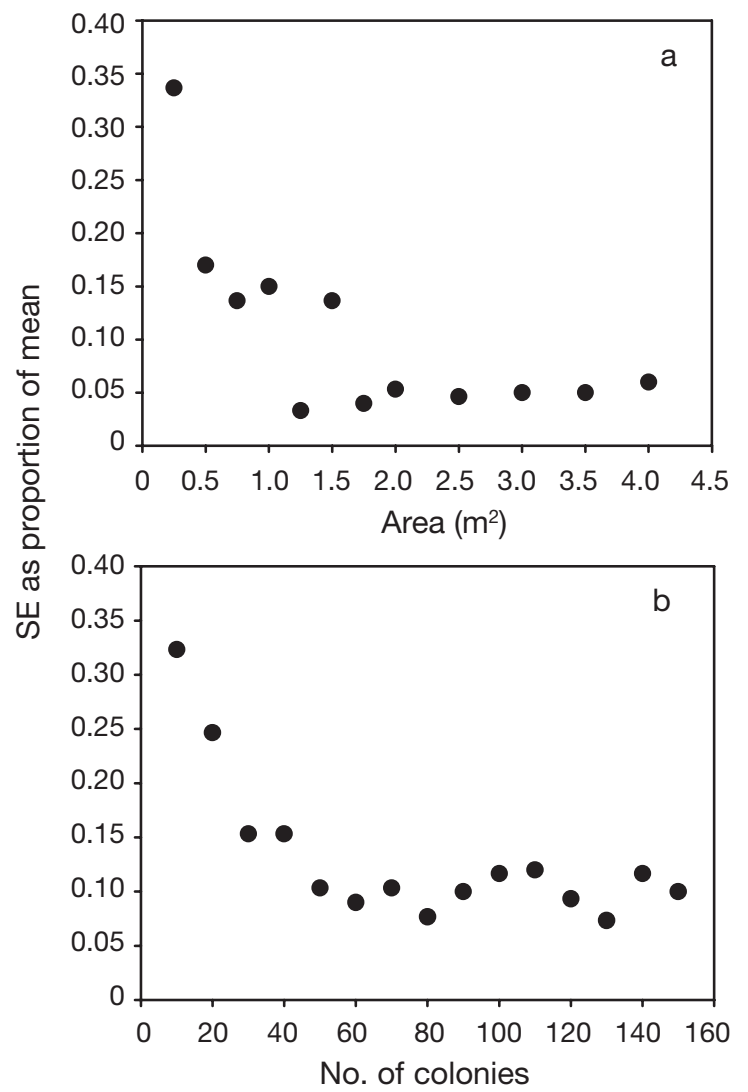

Fig. 2. Eunicella singularis. (a) Variation in SE as a proportion of mean with sample size (area $\mathrm{m}^{2}$ ) to determine minimum sample size for colony density. (b) Variation in SE as a proportion of mean with sample size (no. of colonies) to determine minimum sample size for the extent of injury of the colonies 


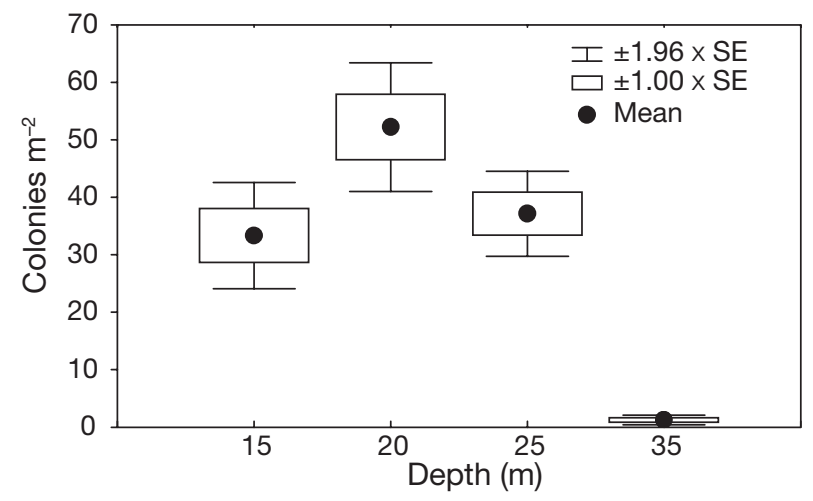

Fig. 3. Eunicella singularis. Variation in density (colonies $\mathrm{m}^{-2}$ ) with depth

taxa were identified to species level. Along with the quantitative assessment of the population, a qualitative examination was conducted every $5 \mathrm{~m}$ in depth, to the maximum depth at each site, in order to determine whether or not the entire population had been affected by the mass mortality event.

Variation in colony density with depth and among sites was analyzed using ANOVA. Data on variation in the extent of injury of the colonies among locations were arc-tan transformed and analyzed using ANOVA. Variation in the proportion of colonies affected by partial mortality was examined using chisquare. Colony size distribution at each site was examined for mean colony height, skewness and kurtosis (Sokal \& Rohlf 1995).

\section{RESULTS}

Eunicella singularis is an abundant species in the north-sloping underwater cliffs of Menorca, between Illa des Porros and Cova de Ses Bruixes. This species dwells in rocky bottom habitats, either on walls or large blocks, forming large patches in exposed areas. The shallowest limit of distribution ranged between 9 and $19 \mathrm{~m}$ (Table 1). Density of colonies varied with depth (1-way ANOVA, $F_{3,152}=11.81, p<0.0001$, Fig. 3). Species abundance increased with depth up to about $20 \mathrm{~m}$ and then progressively declined to values less than 2 colonies $\mathrm{m}^{-2}$ at 35 to $40 \mathrm{~m}$ depth (Fig. 3). A few scattered colonies could be found at $45 \mathrm{~m}$. Eunicella singularis was the predominant gorgonian within the entire surveyed area; however, some colonies of E. Cavolinii (Koch, 1887) were found at $25 \mathrm{~m}$ in Escull de Na Ponça (see below).

During the end of summer and fall 1999, damaged portions of the colonies were observed to lose coenenchyma tissue, leaving denuded axial skeletons that were quickly covered by filamentous algae and hydroids. The high abundance of denuded axes present just after the event (October 1999) contrasted with the only occasional presence of denuded axes observed before the event (e.g. July 1999) and in the following years, when almost all damaged colony portions were covered by a wide array of epibionts (qualitative surveys conducted by E. Ballesteros in July and September 2000, July 2001 and July 2002; continuous qualitative monitoring conducted between 1999 and 2003 by dive instructors; quantitative survey conducted in July 2003). This suggests that the 1999 mortality event was the main reason for the demise and injuries of a large proportion of the population, as quantified during the survey conducted in 2003.

Colonies of Eunicella cavolinii were found at Escull de Na Ponça. A visual inspection of the E. Cavolinii population indicated a large proportion of dead colonies and colonies with a large extent of injury. At all locations, an unusually high number of dead colonies of the bryozoan Myriapora truncata (Pallas, 1766) were also observed on subvertical walls. Several sponge species also exhibited an unusually high proportion of dead specimens.

Tables 1 \& 2 summarize the characteristics of the studied sites. Total colony density varied among sites, ranging between 17 and 44 colonies $\mathrm{m}^{-2}$ with a mean value of 31 colonies $\mathrm{m}^{-2}\left(1\right.$-way ANOVA, $F_{5,210}=14.04$,

Table 1. Eunicella singularis. Characteristics of populations and distribution parameters (max. height, skewness, kurtosis) at study sites. SLD: shallow limit of distribution; Area: sampled area at each site; N: number of colonies examined at each site; $\operatorname{sig}(>)$ : skewness and kurtosis significant if absolute value of coefficient/SE $>2$

\begin{tabular}{|c|c|c|c|c|c|c|c|c|c|c|c|c|c|c|c|}
\hline \multirow{2}{*}{ Locality } & \multirow[t]{2}{*}{ SLD } & \multirow{2}{*}{ Habitat } & \multirow{2}{*}{$\begin{array}{c}\text { Area } \\
\left(\mathrm{m}^{2}\right)\end{array}$} & \multirow{2}{*}{$\mathrm{N}$} & \multirow{2}{*}{$\begin{array}{l}\text { Max. } \\
\text { depth }\end{array}$} & \multicolumn{4}{|c|}{$\longrightarrow$ Height $\longrightarrow$} & \multicolumn{3}{|c|}{ Skewness (g1) } & \multicolumn{3}{|c|}{ Kurtosis (g2) } \\
\hline & & & & & & Mean & SE & Min. & Max. & g1 & SEg1 & $\operatorname{sig}(>2)$ & $\mathrm{g} 2$ & SEg2 & $\operatorname{sig}(>2)$ \\
\hline Illa des Porros & 19 & Large blocks & 7.8 & 129 & 40 & 13.6 & 1.0 & 3.0 & 31.5 & 0.80 & 0.34 & 2.35 & 0.05 & 0.67 & 0.08 \\
\hline Cap de Cavalleria & $12-13$ & Wall & 8.5 & 317 & 35 & 12.8 & 0.3 & 5.0 & 26.0 & 0.54 & 0.18 & 2.95 & -0.06 & 0.37 & -0.15 \\
\hline Cap Roig-Patró Pere & 13 & Wall & 7.5 & 301 & 40 & 13.2 & 0.4 & 3.5 & 32.0 & 0.76 & 0.18 & 4.15 & 0.36 & 0.37 & 0.99 \\
\hline Escull de Na Ponça & $9-10$ & Wall & 8.0 & 353 & 28 & 15.3 & 0.4 & 1.5 & 31.0 & -0.02 & 0.15 & -0.11 & -0.27 & 0.30 & -0.90 \\
\hline Punta Na Guiemassa & 15 & Large blocks & 8.8 & 263 & 27 & 15.3 & 0.5 & 5.0 & 27.5 & 0.29 & 0.21 & 1.38 & -0.40 & 0.42 & -0.95 \\
\hline Cova de Ses Bruixes & 15 & Large blocks & 13.5 & 286 & 28 & 13.1 & 0.4 & 4.0 & 32.0 & 0.67 & 0.20 & 3.34 & 0.38 & 0.40 & 0.95 \\
\hline
\end{tabular}


Table 2. Eunicella singularis. Assessment of mass mortality event at different sites and depths. D: density assessment; DI: determination of extent of injury of the colonies; QA: qualitative assessment of the event; na: not available; NP: species not present; +: population affected by the event

\begin{tabular}{|c|c|c|c|c|c|c|}
\hline \multirow[t]{2}{*}{ Depth (m) } & \multicolumn{6}{|c|}{ - Locality } \\
\hline & $\begin{array}{c}\text { Illa des } \\
\text { Porros }\end{array}$ & $\begin{array}{c}\text { Cap de } \\
\text { Cavalleria }\end{array}$ & $\begin{array}{c}\text { Cap } \\
\text { Roig-Patró Pere }\end{array}$ & $\begin{array}{l}\text { Escull de } \\
\text { Na Ponça }\end{array}$ & $\begin{array}{l}\text { Punta Na } \\
\text { Guiemassa }\end{array}$ & $\begin{array}{c}\text { Cova de } \\
\text { Ses Bruixes }\end{array}$ \\
\hline $0-5$ & NP & NP & NP & NP & NP & NP \\
\hline$>5-10$ & NP & NP & NP & NP & NP & NP \\
\hline$>10-15$ & NP & NP & NP & NP & NP & NP \\
\hline$>15-20$ & NP & D-DI+ & D-DI+ & D-DI+ & D-DI+ & D-DI+ \\
\hline$>20-25$ & D-DI+ & $\mathrm{QA}+$ & D-DI+ & $\mathrm{QA}+$ & $\mathrm{QA}+$ & $\mathrm{QA}+$ \\
\hline$>25-30$ & DI+ & $\mathrm{QA}+$ & D-DI+ & $\mathrm{QA}+$ & $\mathrm{QA}+$ & $\mathrm{QA}+$ \\
\hline$>30-35$ & DI+ & NP & NP & na & na & na \\
\hline$>35-40$ & DI+ & na & D-DI+ & na & na & na \\
\hline
\end{tabular}

$\mathrm{p}<0.0001$, Fig. 4a). The species showed highest densities in the 15 to $20 \mathrm{~m}$ depth range (Fig. 3). A large proportion of dead colonies completely covered by epibionts was observed at all sites and over the entire range of depths where the species was present (Table 2, Fig. 4b). The extent of injury to colonies increased with depth up to $25 \mathrm{~m}$ at Illa des Porros and Cap Roig-Patró Pere, but this pattern reversed below $30 \mathrm{~m}$ at Illa des Porros (Fig. 5).
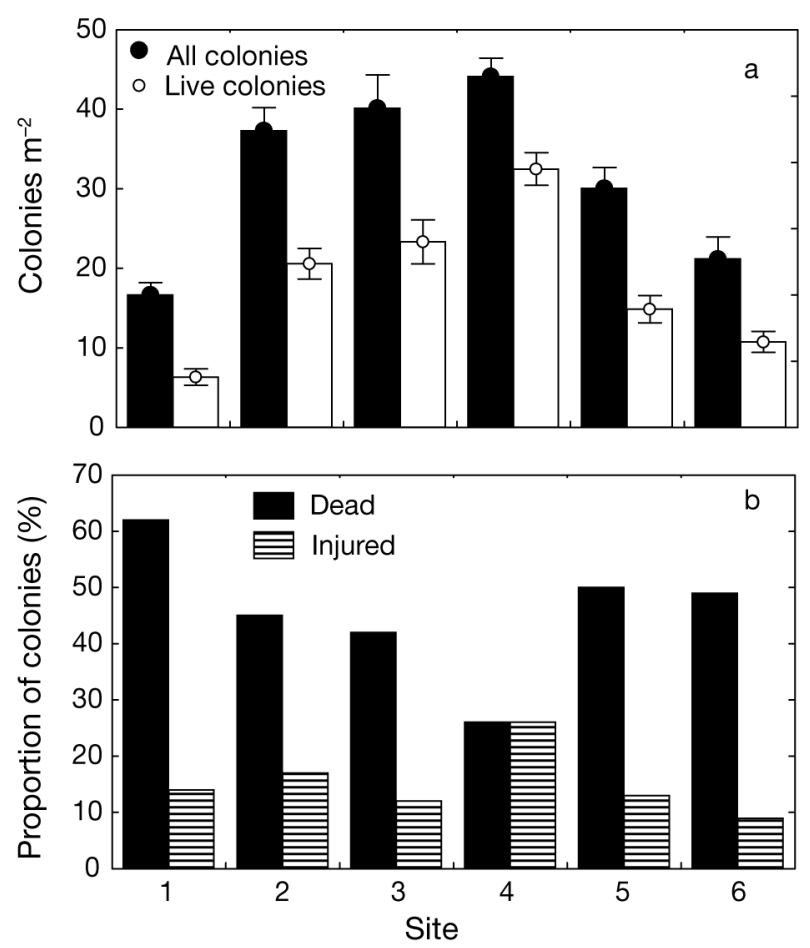

Fig. 4. Eunicella singularis. (a) Density of all colonies (dead and living) and live colonies at each site (mean \pm SE). (b) Proportion of dead and injured colonies at each site. Site numbers as in Fig. 1
Examination of the depth range of highest densities (15 to 20 m, Fig. 3) revealed $59 \%$ of the colonies (975 of 1649 colonies observed at all sites) to have some injury. The proportion of dead colonies varied among sites and ranged between 26 and $62 \%$, with an overall mean value of $46 \%$ of the population $\left(\chi^{2}=15.26\right.$, $\mathrm{df}=5$, $\mathrm{p}<0.0093$, Fig. 4a). Average proportion of dead colonies was inversely correlated with density $\left(\mathrm{r}^{2}=\right.$ 0.77, $\mathrm{N}=6, \mathrm{p}<0.0210$, Fig. 6). The proportion of dead colonies at low density sites was about 2-fold higher than at high density sites. If all colonies are considered (i.e. live and dead colonies), the extent of injury varied among locations (1-way ANOVA, $F_{5,1643}=8.26, \mathrm{p}<$ 0.0001, Fig. 7) and ranged from $37 \%$ at Escull de $\mathrm{Na}$ Ponça to $67 \%$ at Illa des Porros with a mean of $50 \%$.

The proportion of live colonies affected by partial mortality exhibited lower variability among sites than did dead colonies, ranging from 9 to $26 \%$ with a mean

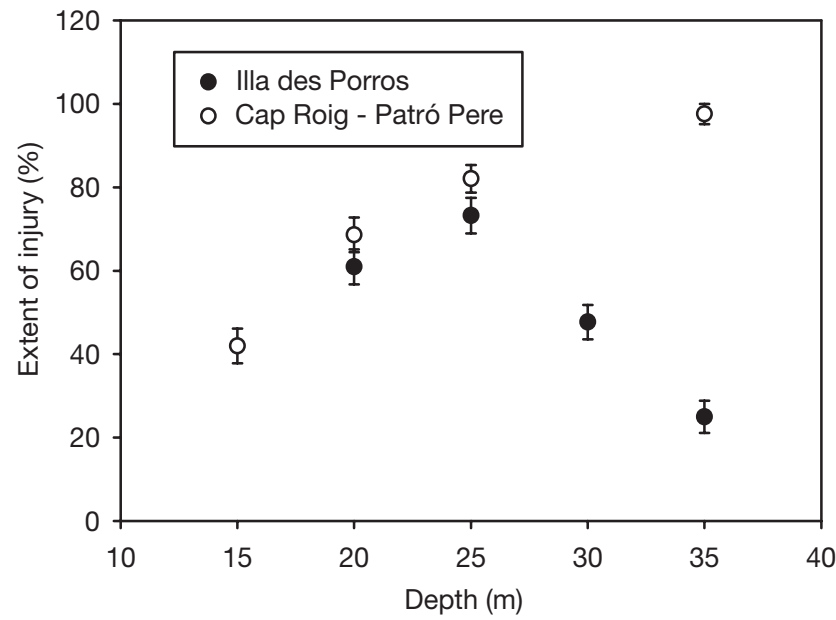

Fig. 5. Eunicella singularis. Variation in the extent of injury to colonies (\%) with depth $(\mathrm{m})$ at 2 locations (mean $\pm \mathrm{SE}$ ). (a) Illa des Porros, (b) Cap Roig-Patró Pere 


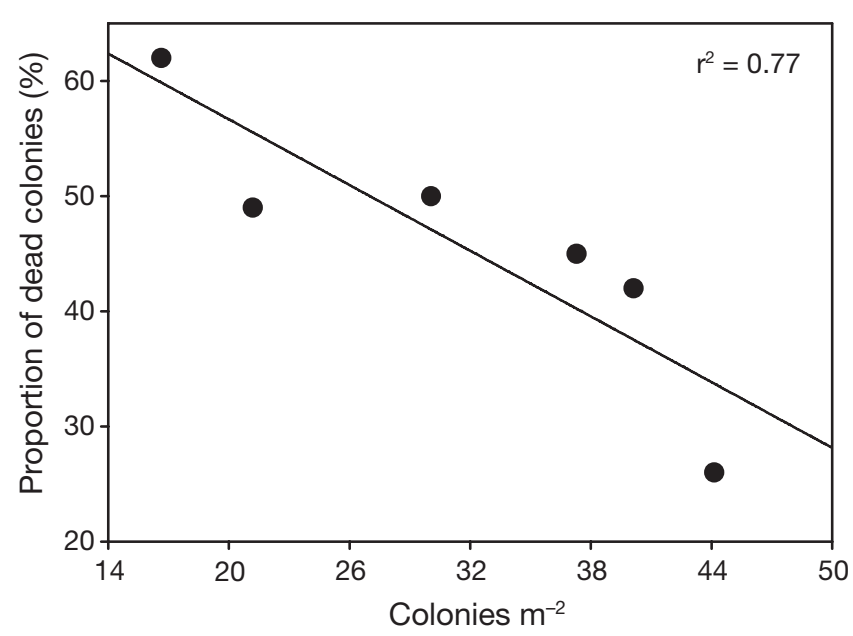

Fig. 6. Eunicella singularis. Relationship between density and proportion of dead colonies

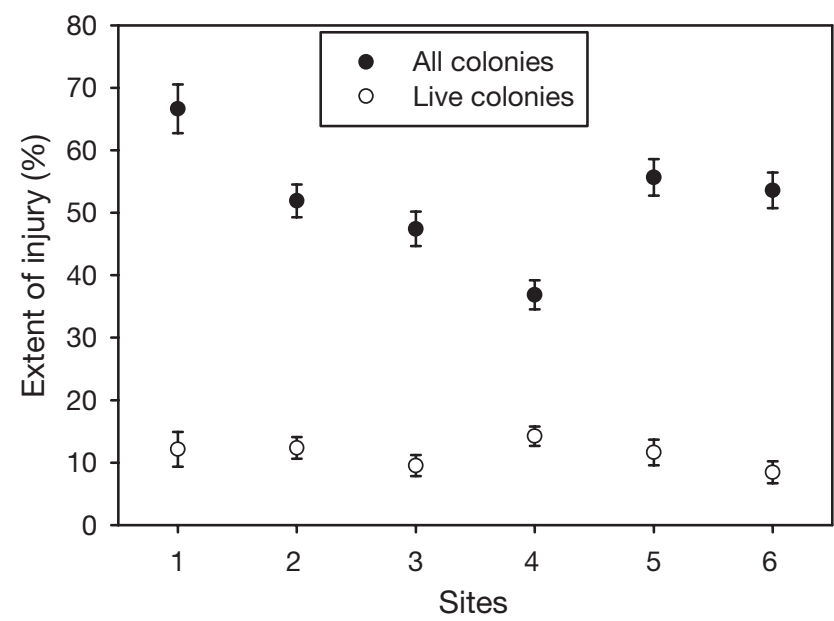

Fig. 7. Eunicella singularis. Extent of injury to colonies (\%) at each site for all colonies $(\bullet)$ and live colonies $(0$, mean $\pm \mathrm{SE})$. Site numbers as in Fig. 1

of $15 \%\left(\chi^{2}=11.53, \mathrm{df}=5, \mathrm{p}=0.0418\right.$, Fig. $\left.4 \mathrm{~b}\right)$. The extent of injury of live colonies did vary among sites within a relatively narrow range (8 to $14 \%$ ), with a mean of $12 \%$ of total colony surface (1-way ANOVA, $F_{5,929}=2.91, \mathrm{p}<0.0128$, Fig. 7$)$. The extent of injury of live colonies increased with colony size (1-way ANOVA, $F_{2,932}=15.15, \mathrm{p}<0.0001$, Fig. 8).

Live colonies ranged in height between 1.5 and $32 \mathrm{~cm}$ (Table 1). Four of the 6 examined populations showed positive skewness $(0.69 \pm 0.06 \mathrm{SE})$ and 2 populations showed symmetric size distribution (Table 1, Fig. 9). This indicated that large size classes were not prevalent in any of the populations. Size structure of live colonies was dominated by colonies 10 to $15 \mathrm{~cm}$ in maximum height at all sites but Escull de Na Ponça, where the dominant height of colonies was 15 to $20 \mathrm{~cm}$.
The proportion of colonies $\leq 10 \mathrm{~cm}$ ranged between 19 and $34.7 \%$, with a mean of $28.9 \pm 2.9 \%$ (SE). None of the populations exhibited significant kurtosis (Table 1).

Macroscopic organisms covered the axes of the injured gorgonian colonies and included filamentous and calcareous algae, hydrozoans, bryozoans and sponges. Among all taxa, the dominant group was filamentous algae, which was present in $96 \%$ of all colonies exhibiting injury; other groups were present in less than $6 \%$ of the injured colonies. Colonies exhibiting some areas not colonized by macroscopic organisms (i.e. bare axes) accounted for $6 \%$ of the colonies.

\section{DISCUSSION}

Along the north coast of Menorca in 2003, a mean of $59 \%$ of Eunicella singularis populations exhibited injury and $46 \%$ of colonies were dead. The qualitative observations conducted (1) before summer 1999, (2) shortly after the event and (3) during the following years allowed us to clearly identify the end of the summer of 1999 as the period of occurrence of the mass mortality event. As reported in previous papers describing the 1999 mass mortality event (Cerrano et al. 2000, Perez et al. 2000), mortality resulted in partial or complete loss of the coenenchyme followed by denudation of the colony axes. These denuded axes were subsequently colonized by epibionts (algae and several invertebrates species), indicating that the large amount of epibionts present on the colonies was not the cause of partial or complete death of the colonies but a consequence of colonization of free space after the death of the gorgonian coenechyma tissue (Cerrano et al. 2000, Perez et al. 2000). In 2003, populations of $E$. singularis were characterized by a large number of skeletons and a variable proportion of colonies with epibionts.

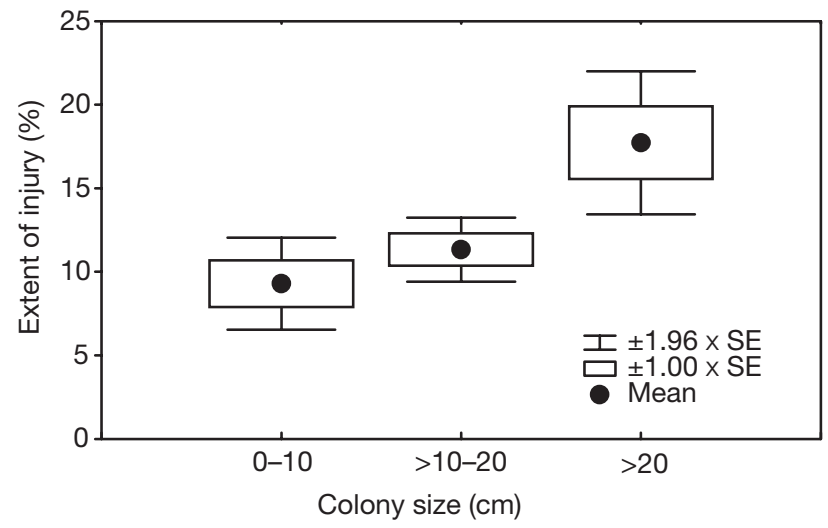

Fig. 8. Eunicella singularis. Variation in the extent of injury of live colonies (\%) with colony size (max. height in $\mathrm{cm}$ ) 


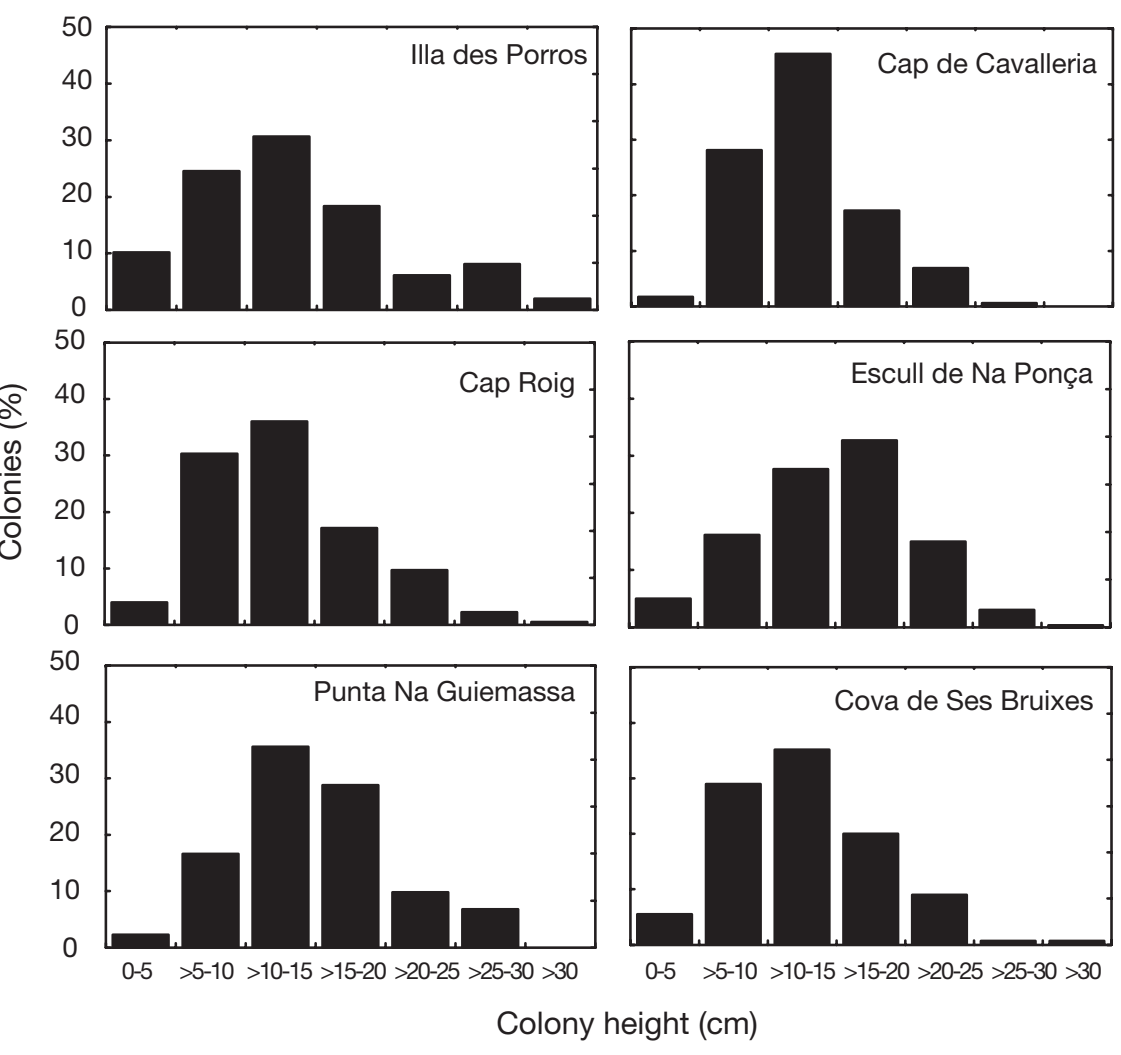

Fig. 9. Eunicella singularis. Size class structure (max. height in $\mathrm{cm}$ ) of live colonies at each site

A drawback of this study was the lack of available quantitative baseline data prior to the event. This was also the case for other studies (Cerrano et al. 2000, Perez et al. 2000) and is a consequence of the unpredictable nature of such an event. Nevertheless, biological monitoring surveys conducted regularly from 1998 to 2003 within the Medes Islands Marine Reserve-an area unaffected by the 1999 mass mortality eventshowed that, at any given time, $<2 \%$ of colonies are dead, $<10 \%$ of colonies are affected by partial mortality, and that denuded axes are present $<2 \%$ of the colonies (authors' unpubl. data). Furthermore, similar values were observed during the examination of 21 populations of this species distributed over $1000 \mathrm{~km}$ along the Mediterranean coast of Spain (from Cap de Creus to Cabo de Palos, authors' unpubl. data). This provided a reference framework for the rates of injury of this species under natural conditions, against which to contrast the effect of the 1999 event at the study area.

Another drawback was that, due to logistic and financial reasons, quantitative assessment of the impact was not possible until several years after the occurrence of the event. Therefore, our assessment could not distinguish whether the death of the colonies occurred immediately after the event or was the result of a delayed impact. However, two sources may contribute to a determination of whether a delayed effect played a significant role in the overall impact of the event. First, studies conducted shortly after the occurrence of the 1999 event found that the proportion of affected colonies (e.g. 65 to $90 \%$ of Eunicella singularis colonies, 75 to $90 \%$ of Paramuricea clavata [Risso, 1826] colonies [Cerrano et al. 2000]; $\leq 90 \%$ of $E$. singularis and $P$. clavata colonies [Perez et al. 2000]; $76 \pm 8 \%$ of $P$. clavata colonies [Linares et al. 2005]) was much higher than that of dead colonies (20 to $25 \%$ of E. singularis colonies, 10 to $20 \%$ of $P$. clavata colonies [Cerrano et al. 2000]; $9 \pm 2 \%$ of P. clavata colonies [Linares et al. 2005]). Second, monitoring of temporal variability of the effects of the mass mortality event on the gorgonian P. clavata at Port-Cros during a 4 yr study allowed us to determine that estimates of mortality conducted after the event may actually underestimate the impact of the event. This is due to the fact that the extent of injury to colonies was positively correlated to mortality rate (Linares et al. 2005), as is consistent with results from another ongoing long term survey of the event (Provence region, J. Garrabou pers. obs.). On the basis of these 2 lines of evidence, our hypothesis is that the delayed effect of the event in terms of mortality of colonies was similar or higher than that of the immediate effect. Assessment of the event 4 years after its occurrence provided an integration of the accumulated consequences of the event on this population. Nevertheless, immediate assessment of the population would have been desirable because the injured skeletal axes become broken over time (Bavestrello \& Boero 1986). Although breakage is a slow-paced process, we cannot disregard the fact that some colonies may have become fragmented and, therefore, that our study may have represented an underestimation of the real impact of the event.

The surveyed locations covered the entire geographic range of where the species is abundant in Menorca (extensive surveys of rocky communities indicated that only scattered colonies can be found on other 
parts of the island, authors' unpubl. data). Thus, the mass mortality event greatly affected the Eunicella singularis populations of Menorca. Although the impact of the mass mortality varied with depth among locations, the entire depth range of this species (15 to $40 \mathrm{~m}$ ) was affected. Previous reports indicated that E. singularis was affected by the mass mortality event at other NW Mediterranean areas, from the Tuscan Archipelago to Marseille (Cerrano et al. 2000, Perez et al. 2000), but the present study reports the deepest depth where the species has been observed to be affected by the event (this study: 40 m; 27 m: Cerrano et al. 2000; 30 m: Perez et al. 2000). Nevertheless, other gorgonian species were also affected at $40 \mathrm{~m}$ at other locations (Cerrano et al. 2000, Perez et al. 2000). The fact that the event affected the E. singularis populations down to a depth of $40 \mathrm{~m}$ indicates that the impact of this event along the north coast of Menorca was large not only because of the large proportion of colonies that were affected, but also because this species occurs deeper in this area than at other studied locations in the Provence region and the eastern Ligurian Sea.

The impact of the event varied among sites. An important fraction of the variability among sites is associated with the positive relationship between the proportion of dead colonies and colony density (Fig. 6). Our interpretation is that differences in densities often reflect variations in the environmental conditions that affect population development. Thus, low density populations occur in less favorable conditions than do high density populations. Therefore, low density populations should be more susceptible than high density populations to environmental disturbances. However, Cerrano et al. (2000) did not observe density-dependent mortality of Eunicella singularis in the eastern Ligurian Sea. There was also no density-dependent mortality of the gorgonian Paramuricea clavata in the Provence region (Linares et al. 2005). The lack of density-dependence in these earlier studies could be related to the small degree of variation in density at these sites (eastern Ligurian Sea, E. singularis: generally 1 to 15 colonies $\mathrm{m}^{-2}$ [Cerrano et al. 2000]; Provence region, $P$. clavata: generally 25 to 38 colonies $\mathrm{m}^{-2}$ [Linares et al. 2005]). Nevertheless, the 1999 mass mortality event displayed high spatial variability at reduced scales, as documented by previous reports on different species (Cerrano et al. 2000, Perez et al. 2000, Garrabou et al. 2001, Linares et al. 2005). Differences in the impact of the event in the deep waters of 2 depth transects (Illa des Porros and Cap Roig-Patró Pere, Fig. 5) may be related to high spatial variability among sites.

Although massive mortality and injury of the gorgonian species Eunicella singularis was reported for a large area along the coast of Provence (Perez et al.
2000) and Liguria (Cerrano et al. 2000), quantification of the impact of the mortality was only conducted at Tino Island (Cerrano et al. 2000). Our estimates of the proportion of colonies affected by partial mortality (9 to $26 \%$ of colonies) were much lower than those of previous reports (65 to $90 \%$ of the colonies, Cerrano et al. 2000). This discrepancy is most probably related to the capacity of this species for healing injuries. Many gorgonians fracture branches after being covered by epibionts (Bavestrello \& Boero 1986), a process that reduces competition between the coenenchyma and epibionts. Branch fracture usually leaves a recognizable scar. A large proportion of uninjured colonies exhibiting signs of healed lesions was observed during the field component of this study, suggesting that in 1999 the proportion of colonies exhibiting partial mortality might have been much higher, probably similar to that previously reported from the Ligurian Sea (Cerrano et al. 2000). The proportion of live colonies exhibiting some injury in 2003 (15\%), 4 years after the mortality event, together with the high proportion of colonies without epibionts $(40 \%)$, suggests that colonies from all sites were recovering, reducing the extent of injury. Therefore, the average proportion of living colonies exhibiting some injury (15\%) was only slightly higher than that observed in unaffected populations (10\%, Medes Island Marine Reserve, authors' unpubl. data).

Our estimate of the percentage of colonies that were completely dead ( $45 \%$ of the population) was about twice that reported by Cerrano et al. (2000) (20 to $25 \%$ ). This points to the crucial role of delayed mortality in the evaluation of the impact of the event. Similar results were also observed for Paramurica clavata, when contrasting estimates made shortly after the event with the accumulated impact observed several years later (Linares et al. 2005). The delayed effect of the event on E. singularis in our study was most probably due to increased mortality of colonies affected by high levels of injury, as was documented for P. clavata (Linares et al. 2005).

The current size structure of the populations of Eunicella singularis points to low recruitment rates after the mortality event (skewness: 0.6; proportion of colonies

$10 \mathrm{~cm}: 28.9 \%$ ). This could be related to the low and episodic recruitment patterns exhibited by most gorgonians (Lasker 1990, Yoshioka 1994, Coma et al. 2004). However, annual monitoring of the E. singularis population in Medes Island Marine Reserve (1998 to 2003), together with examination of 21 populations of the species distributed over $1000 \mathrm{~km}$ along the Mediterranean coast of Spain, provides a reference framework for recruitment patterns. These data have a skewness coefficient $(1.21 \pm 0.15 \mathrm{SE}$, authors' unpubl. data) and the proportion of colonies $10 \mathrm{~cm} \mathrm{(46.6 \pm}$ 
$5.5 \%$ SE, authors' unpubl. data) is about 2-fold that observed in Menorca populations. Thus, populations of E. singularis from several localities along the Spanish coast are mainly composed of colonies in small size classes. Therefore, low recruitment observed during the latter years of survey at Menorca was probably related to the mass mortality event, with extensive injury affecting the reproductive effort of this species. Similar changes in reproductive output have been observed in the gorgonian Paramuricea clavata (authors' unpubl. data) and the tropical species Gorgonia ventalina (Petes et al. 2003).

This study has shown that the 1999 mass mortality event in Menorca not only affected the gorgonian Eunicella singularis, but other species including Eunicella cavolinii and the bryozoan Myriapora truncata. Thus, the mass mortality event of suspension-feeders that affected most of the Liguria (Cerrano et al. 2000) and Provence (Perez et al. 2000) coasts exhibited a much wider geographic range than initially reported, as Menorca is located about 400 to $700 \mathrm{~km}$ from the other areas.

The mortality of at least $45 \%$ of the population over a 4 yr time period (1999 to 2003) represents a major impact on Eunicella singularis populations in Menorca. This mortality is similar to that documented for Paramuricea clavata in Port Cros (48\%, Linares et al. 2005) over the same time period, again highlighting the crucial role of delayed impacts of these kinds of events. Hypotheses about the cause of this event focus on the occurrence of a distinctive climatic anomaly during late summer and early fall 1999 (Cerrano et al. 2000, Perez et al. 2000, Romano et al. 2000, Martin et al. 2002, Coma \& Ribes 2003). Given the trends of global warming, the frequency of similar events may increase in the future (Cerrano et al. 2000, Coma et al. 2000, Perez et al. 2000, Garrabou et al. 2001, Coma \& Ribes 2003). However, the ultimate cause of the event is still uncertain and is a subject of current research. Nevertheless, even if this was a rare, low frequency event, the extent of this event (in the order of $1000 \mathrm{~km}$ ) and the magnitude of delayed effects (Linares et al. 2005, this study) points to the important role that these catastrophic events play in the population dynamics of long-lived Mediterranean species such as E. singularis and P. clavata (and possibly Corallium rubrum, Garrabou et al. 2001, and some sponges, Perez et al. 2000). Additional consequences could result from the reduction in reproductive effort and potential repercussions on the success of future recruitment. Thus, the 1999 mortality event represents one of the strongest disturbances ever recorded for any temperate gorgonian species over such an extended geographic area, and it is similar to events observed in tropical gorgonians in the Caribbean Sea during the 1980s (e.g. Lasker et al. 1984, Garzón-Ferreira \& Zea 1992) and the 1990s (e.g. Nagelkerden et al. 1997, Kim \& Harvell 2004, Lasker 2005). This highlights the major role of low frequency disturbance events on the structure and dynamics of gorgonians populations and ramifications for community structure, given that gorgonians are key structural and functional organisms within these communities.

Acknowledgements. We thank Evelyn F. Cox for providing helpful comments and for revising the English version of the manuscript, and Roger N. Hughes for his comments and suggestions that further contributed to its improvement. We are grateful to the Direcció General de Pesca i Cultius Marins del Govern de les Illes Balears for providing diving permits for the Reserva Marina del Nort de Menorca. Financial support for this work was provided by research grants REN200201631/MAR and CTM2004-03120/MAR from the Ministerio de Educación y Ciencia of Spain.

\section{LITERATURE CITED}

Ballesteros E (2006) Mediterranean coralligenous assemblages: a synthesis of the present knowledge. Oceanogr Mar Biol Annu Rev 44:123-195

Bavestrello G, Boero F (1986) Necrosi e rigenerazione in Eunicella cavolinii in Mar Ligure. Boll Mus Ist Biol Univ Genova 52:295-300

Boero F (1996) Episodic events: their relevance to ecology and evolution. PSZN I: Mar Ecol 17:237-250

Bruno JF, Bertness MD (2001) Habitat modification and facilitation in benthic marine communities. In: Bertness MD, Gaines SD, Hay ME (eds) Marine community ecology. Sinauer Associates, Sunderland, MA, p 201-218

Cerrano C, Bavestrello G, Bianchi CN, Cattaneo-Vietti R and 8 others (2000) A catastrophic mass-mortality episode of gorgonians and other organisms in the Ligurian Sea (NW Mediterranean), summer 1999. Ecol Lett 3:284-293

Coma R, Ribes M (2003) Seasonal energetic constraints in Mediterranean benthic suspension feeders: effects at different levels of ecological organization. Oikos 101: $205-215$

Coma R, Ribes M, Gili JM, Zabala M (2000) Seasonality in coastal benthic ecosystems. Trends Ecol Evol 15:448-453

Coma R, Pola E, Ribes M, Zabala M (2004) Long-term assessment of the patterns of mortality of a temperate octocoral in protected and unprotected areas: a contribution to conservation and management needs. Ecol Appl 14: $1466-1478$

Conradi M, Megina C, López-González JP (2004) Sibling species of copepods in association with Mediterranean gorgonians. Sci Mar 68:85-96

Garrabou J, Perez T, Sartoretto S, Harmelin JG (2001) Mass mortality event in red coral Corallium rubrum populations in Provence region (France, NW Mediterranean). Mar Ecol Prog Ser 217:263-272

Garzón-Ferreira J, Zea S (1992) A mass mortality of Gorgonia ventalina (Cnidaria: Gorgoniidae) in the Santa Marta area, Caribbean coast of Colombia. Bull Mar Sci 50: $522-526$

Harvell CD, Kim K, Burkholder JM, Colwell RRI and 9 others (1999) Emerging marine diseases-climate links and anthropogenic factors. Science 285:1505-1510 
Harvell CD, Aronson R, Baron N, Connell J and 13 others (2004) The rising tide of ocean diseases: unresolved problems and research priorities. Front Ecol Environ 2:375-382

Hughes TP, Baird AH, Bellwood DR and 14 others (2003) Climate change, human impacts, and the resilience of coral reefs. Science 301:929-933

Huston MA (1979) A general hypothesis of species diversity. Am Nat 113:81-101

Jones CG, Lawton JH, Shachak M (1994) Organisms as ecosystem engineers. Oikos 69:373-386

Kim K, Harvell CD (2004) The rise and fall of a six year coralfungal epizootic. Am Nat 164:S52-S63

Lasker HR (1990) Clonal propagation and population dynamics of a gorgonian coral. Ecology 71:1578-1589

Lasker HR (2005) Gorgonian mortality during a thermal event in the Bahamas. Bull Mar Sci 76:155-160

Lasker HR, Peters EC, Coffroth MA (1984) Bleaching of reef coelenterates in the San Blas Islands, Panama. Coral Reefs 3:183-190

Linares C, Coma R, Diaz D, Zabala M, Hereu B, Dantart L (2005) Immediate and delayedeffects of a mass mortality event on gorgonian population dynamics and benthic community structure in the NW Mediterranean Sea. Mar Ecol Prog Ser 305:127-137

MacArthur RH, Recher H, Cody M (1966) On the relation between habitat selection and species diversity. Am Nat 100:319-332

Martin Y, Bonnefont JL, Chancerelle L (2002) Gorgonians mass mortality during the 1999 late summer in French Mediterranean coastal waters: the bacterial hypothesis. Water Res 36:779-782

Nagelkerken I, Buchan K, Smith GW, Bonair K and 10 others (1997) Widespread disease in Caribbean sea fans. II. Pat-

Editorial responsibility: Roger Hughes (Contributing Editor), Bangor, UK terns of infection and tissue loss. Mar Ecol Prog Ser 160: 255-263

Perez T, Garrabou J, Sartoretto S, Harmelin JG, Francour P, Vacelet J (2000) Mortalité massive d'invertébrés marins: un événement sans précédent en Méditerranée nord-occidentale. CR Acad Sci Paris III 323:853-865

Petes LE, Harvell CD, Peters EC, Webb MAH, Mullen KM (2003) Pathogens compromise reproduction and induce melanization in Caribbean sea fans. Mar Ecol Prog Ser 264:167-171

Romano JC, Bensoussan N, Younes WAN, Arlhac D (2000) Anomalies thermiques dans les eaux du golfe de Marseille durant l'été 1999. Une explication partielle de la mortalité d'invertébrés fixés. CR Acad Sci Paris III 323:415-427

Sokal R, Rohlf FJ (1995) Biometry. The principles and practice of statistics in biological research, 3rd edn. Freeman, New York

Weinberg S (1978) Mediterranean octocorallian communities and the abiotic environment. Mar Biol 49:41-57

Wendt PH, van Dolah RF, O'Rourke CB (1985) A comparative study of the invertebrate macrofauna associated with seven sponge and coral species collected from the South Atlantic Bight. J Elisha Mitchell Sci Soc 101:187-203

Wilkinson C, Lindén O, Cesar H, Hodgson G, Rubens J, Strong AE (1999) Ecological and socioeconomic impacts of 1998 coral mortality in the Indian ocean: an ENSO impact and a warning of future changes? Ambio 28:188-196

Yoshioka PM (1994) Size-specific life history pattern of a shallow-water gorgonian. J Exp Mar Biol Ecol 184: 111-122

Yoshioka PM, Yoshioka BB (1991) A comparison of the survivorship and growth of shallow-water gorgonian species of Puerto Rico. Mar Ecol Prog Ser 69:253-260

Submitted: February 24, 2006; Accepted: May 10, 2006

Proofs received from author(s): November 7, 2006 